\title{
Prognostic value of vascular endothelial growth factor and hypoxia-inducible factor $1 \alpha$ in canine malignant mammary tumors
}

\author{
MARINA GOBBE MOSCHETTA ${ }^{1,2}$, LARISSA BAZELA MASCHIO ${ }^{2,3}$, \\ BRUNA VICTORASSO JARDIM-PERASSI ${ }^{2,3}$, GABRIELA BOTTARO GELALETI ${ }^{2,3}$, \\ JULIANA RAMOS LOPES ${ }^{2,3}$, CAMILA LEONEL ${ }^{2,3}$, NAIANE DO NASCIMENTO GONÇALVES ${ }^{1,2}$, \\ LÍVIA CARVALHO FERREIRA ${ }^{2,3}$, GUSTAVO RODRIGUES MARTINS ${ }^{1,2}$, \\ THAIZ FERRAZ BORIN ${ }^{1,2}$ and DEBORA APARECIDA PIRES DE CAMPOS ZUCCARI ${ }^{2,4}$ \\ ${ }^{1}$ PostGraduate Program in Health Sciences, Faculty of Medicine of Sao Jose do Rio Preto/FAMERP; \\ ${ }^{2}$ Laboratory of Cancer Molecular Investigation (LIMC), Faculty of Medicine of Sao Jose do Rio Preto/FAMERP; \\ ${ }^{3}$ PostGraduate Program in Genetics, Sao Paulo State University 'Julio de Mesquita Filho'/UNESP-IBILCE; \\ ${ }^{4}$ Department of Molecular Biology/FAMERP and Program of PostGraduate in Genetics/ \\ UNESP-IBILCE, São José do Rio Preto, SP, Brazil
}

Received October 8, 2014; Accepted December 4, 2014

DOI: $10.3892 /$ or.2015.3856

\begin{abstract}
Mammary tumors are the most common type of tumor in dogs, with approximately half of these tumors being malignant. Hypoxia, characterized by oxygen levels below normal, is a known adverse factor to cancer treatment. The hypoxia-inducible factor $1 \alpha$ (HIF-1 $\alpha$ ) is a central regulator of the pathophysiological response of mammalian cells to low oxygen levels. HIF- $1 \alpha$ activates the transcription of vascular endothelial growth factor (VEGF), which in turn promotes angiogenesis through its ability to stimulate the growth, migration and invasion of endothelial cells to form new blood vessels, contributing to tumor progression. In this study, we evaluated the serum concentration and gene expression of VEGF and HIF-1 $\alpha$ linking them with clinicopathological parameters and survival of dogs with mammary tumors in order to infer the possible prognostic value of these factors. We collected blood and tumor fragments of 24 female dogs with malignant mammary tumors (study group) and 26 non-affected female dogs (control group) to verify the gene expression of VEGF and HIF- $1 \alpha$ by quantitative real-time PCR (qPCR) and the
\end{abstract}

Correspondence to: Professor Debora Ap. Pires de Campos Zuccari, Laboratory of Cancer Molecular Investigation (LIMC), Faculty of Medicine of Sao Jose do Rio Preto/FAMERP, Avenue Brigadeiro Faria Lima, 5416, Vila São Pedro, 15090-000 São José do Rio Preto, SP, Brazil

E-mail: debora.zuccari@famerp.br

Key words: angiogenesis, canine mammary tumors, hypoxiainducible factor- $1 \alpha$, prognostic markers, vascular endothelial growth factor serum levels by ELISA (enzyme-linked immunosorbent). The results showed high serum levels of VEGF in the study group and its correlation between abundant vascularization, lymph node involvement, metastasis, death rate and low survival $(p<0.05)$. The serum percentage of HIF- $1 \alpha$ in female dogs with mammary neoplasia was lower than that in the control group and higher in female dogs with tumor metastasis and history of tumor recurrence $(\mathrm{p}<0.05)$. Regarding gene expression, there was a gene overexpression of VEGFA in female dogs with poor outcome, in contrast to the gene underexpression of HIF-1A. Taken together, these results suggested that VEGF is important in tumor progression and can be used as a potential prognostic marker in the clinic and may be useful in predicting tumor progression in dogs with mammary neoplasia.

\section{Introduction}

Mammary tumors are the most common neoplastic process in female dogs, representing $52 \%$ of neoplasms, of which $41-53 \%$ are histologically diagnosed as malignant, with distant metastasis being the most common cause of death in female dogs (1-6). Canine mammary tumors (CMTs) are similar to human breast cancers $(5,7)$, thus they are a suitable animal model for the study of mammary carcinogenesis in the two species $(2,8)$.

Prognosis is directly associated with factors such as tumor size, lymph-node involvement, presence of distant metastasis, histological type, histologic grade and intravascular growth (9). Therapy based on prognostic assessment enables the application of different therapeutic modalities used in cancer treatment with the intensity and effectiveness appropriate for each patient, increasing survival $(10,11)$.

Angiogenesis is a process in which new blood vessels are formed from pre-existing vasculature (12), which is necessary 
to supply nutrients and maintain homeostasis in the tissues of the body (13). This process has been shown to be a necessary process for oncogenesis as well, in addition to subsequent tumor growth and dissemination through metastases (14).

Angiogenesis is regulated by a number of pro- and antiangiogenic factors, such as vascular endothelial growth factor (VEGF) and hypoxia-inducible factor (HIF) $(15,16)$. These factors, which are released by tumor cells promote activation, proliferation and migration of endothelial cells to tumor tissue, allowing for the rapid formation of functional neovasculature (17).

HIF transcription factors mediate the primary transcriptional response to hypoxic conditions in normal and neoplastic cells. HIFs form heterodimeric complexes composed of the $\alpha$ and a stable $\beta$ subunit. Together these subunits bind hypoxia response elements (HREs) to hundreds of genes that facilitate the adaptation to hypoxia, specifically promoter elements present in the promoter region of VEGF $(18,19)$.

HIF- $1 \alpha$ is an oxygen-liable subunit, that in normal oxygen conditions is maintained at a low level $(20,21)$ as it is recognized by the Hippel-Lindau tumor suppressor (pVHL) and degraded by the proteasome (22-24). Under hypoxic conditions, pVHL binds to nitric oxide (NO) and the HIF-1 $\alpha$ is not recognized, allowing the migration of HIF-1 $\alpha$ from the cytoplasm to the nucleus, therebey inducing the expression of VEGF $(15,16,25-28)$.

VEGF and its receptors are confirmed signaling pathways in angiogenesis (29). VEGF stimulates endothelial cell proliferation, migration and capillary tube formation $(28,30-31)$. Tumor growth through angiogenesis is directly correlated with VEGF expression in breast cancer (15,16,32-34). It was reported that VEGF expression in canine and feline mammary carcinomas is associated with a more aggressive behavior and a poor diagnosis/prognosis (35-37).

The aims of this study were to determine the serum levels and gene expression of VEGF and HIF-1 $\alpha$ in female dogs with malignant mammary neoplasia, and to verify their correlation with clinicopathological parameters and clinical evolution, aiming to determine its prognostic value.

\section{Materials and methods}

Ethical considerations. This study was approved by the Ethics Committee of Sao Jose do Rio Preto Medical School (protocol no. 5230/2010).

Sample characterization. Peripheral blood samples and tumor fragments from 24 female dogs with malignant mammary neoplasia (study group) and 26 female non-affected dogs (control group) were collected at the veterinary clinics in São José do Rio Preto, SP, Brazil and the surrounding region between 2011 and 2012. Exclusion criteria for the control group were rigorously followed and included females with no tumor history and no detectable disease inflammation/infections in the period prior to the sampling.

Female dogs from the study group were evaluated by the veterinary with respect to physical (age and breed), pathological (time-course, the interval between tumor diagnosis and surgical removal, tumor localization, lymph-node involvement, tumor mass size, clinical staging, ulceration and vascularization) and clinical (metastasis, local recurrence and death) characteristics.

Following the tumor excision and blood collection, the animals of study group were followed for 12 months. During this period the presence of local tumor recurrence, metastasis (confirmed by X-ray) and death were described by the veterinary, allowing the determination of survival time and disease-free survival time (the time from excision until the detection of metastasis and/or recurrence).

The tumor fragments collected at excision were divided into two sections: The first one was fixed in buffered $10 \%$ formaldehyde for $24 \mathrm{~h}$ and paraffin-embedded. Histological sections $(3 \mu \mathrm{m})$ were obtained and stained with hematoxylin and eosin (H\&E) by standard histological procedures for histopathology. The second section was immersed in RNA stabilizing solution, RNAlater (Invitrogen Life Technologies, Eugene, OR, USA) for qPCR analysis.

The parameters employed for the histological classification were performed according to the Canine Mammary Neoplasms Histological Classification, modified from Misdorp et al $(38,39)$ and the clinical staging system (TNM) of canine mammary carcinomas established by Owen (40).

Most of the malignant tumors consisted of simple carcinoma, such as tubulopapillary carcinoma type (16/24) (67\%). The age range of the animals was 7-14 years (mean, 10 years) and $25 \%$ of animals were of indeterminate breed. Among the clinicopathological characteristics, there was a predominance of time course $>6$ months (11/24) $(46 \%)$, tumors with multiple location (14/24) (58\%), lymph-node involvement N0 (17/24) (71\%), tumor mass size $<3 \mathrm{~cm}(12 / 24)(50 \%)$, clinical staging I (10/24) (42\%), tumors without ulceration (20/24) (83\%) and moderate vascularization $(16 / 24)(67 \%)$. The local recurrence rate was $17 \%$, metastasis $25 \%$ and death $33 \%$. The patient characteristics are shown in Table I.

Enzyme-linked immunosorbent assay (ELISA). For the enzyme-linked immunosorbent assay, the blood $(3 \mathrm{ml})$ was collected in a CORVAC serum separator tube (Labor import, São Paulo, SP, Brazil) containing clot activation additive and barrier gel, stored at $4^{\circ} \mathrm{C}$, processed by centrifugation (1,000 x g, $25 \mathrm{~min})$ and passed through a $13-\mathrm{mm}$ serum filter to remove potentially contaminating cells. The serum was immediately cryopreserved at $-80^{\circ} \mathrm{C}(7)$.

Quantification of serum VEGF. VEGF content was determined by using a Quantikine Canine VEGF Immunoassay kit (R\&D Systems, Minneapolis, MN, USA). A specific monoclonal antibody anti-canine VEGF was pre-coated onto a 96-well polystyrene microplate, and $100 \mu \mathrm{l}$ of buffered protein solution, standards and samples were pipetted into the wells. After incubation for $2 \mathrm{~h}$, the microplate was washed three times with $300 \mu \mathrm{l} /$ well. The reaction also included incubations at room temperature with $200 \mu \mathrm{l} /$ well of enzyme-linked polyclonal antibody against VEGF conjugated to horseradish peroxidase for $2 \mathrm{~h}$ followed by another wash and $200 \mu \mathrm{l} /$ well of substrate solution $\left(\mathrm{H}_{2} \mathrm{O}_{2}\right.$ and tetramethylbenzidine) for $25 \mathrm{~min}$. Then, $50 \mu \mathrm{l}$ of stop solution ( $2 \mathrm{~N}$ sulfuric acid) was added to each well and the optical density (OD) was measured at $450 \mathrm{~nm}$ in a microplate reader (Thermo Fisher Scientific, Waltham, MA, USA). The reaction intensity was proportional to the 
Table I. Mean serum concentration of VEGF and serum percentage of HIF-1 $\alpha$ and its correlation with clinicopathological parameters.

\begin{tabular}{lccc}
\hline $\begin{array}{l}\text { Clinicopathological } \\
\text { parameters }\end{array}$ & $\begin{array}{c}\text { Number of } \\
\operatorname{dogs}\end{array}$ & VEGF & HIF-1 $\alpha$ \\
$(\mathrm{pg} / \mathrm{ml})$ & $(\%$ of control) \\
\hline
\end{tabular}

\section{Clinical feature}

Control

Samples

P-value

Age

$<10$ anos

p-value

Tumor location

Multiple

Single

P-value

Time course

1 month

Up to 6 months

More than 6 months

P-value ${ }^{b}$

Tumor mass size

T1

T2

T3

P-value ${ }^{b}$

Lymph node involvement

$$
\begin{aligned}
& \text { N0 } \\
& \text { N1/N2 } \\
& \text { P-value }
\end{aligned}
$$

Metastasis

M0

M1/M2

$\mathrm{P}$-value

Clinical staging

I/II

III/IV

$\mathrm{P}$-value

Ulceration

Yes

No

$\mathrm{P}$-value

Vascularization

Abundant
Moderate
P-value

Recurrence

$$
\begin{aligned}
& \text { Yes } \\
& \text { No } \\
& \text { P-value }
\end{aligned}
$$

Censorship

Death

Alive

$\mathrm{P}$-value
24

26

$11(46 \%)$

$13(54 \%)$

$14(58 \%)$

$10(42 \%)$

\section{$51.77 \pm 4.875$ \\ $136.4 \pm 48.79$ \\ $0.03^{\mathrm{a}}$}

$79.95 \pm 35.46$

$161.3 \pm 78.59$

0.37

$146.2 \pm 71.87$

$96.63 \pm 52.86$

0.59

$22.27 \pm 12.51$
$144.5 \pm 64.98$
$138.7 \pm 84.96$
$p>0.05$

$12(50 \%)$

$4(17 \%)$

$8(33 \%)$

$17(71 \%)$

$7(29 \%)$

$18(75 \%)$

$6(25 \%)$

$12(50 \%)$

$12(50 \%)$

$4(17 \%)$

$20(83 \%)$

$8(33 \%)$

$16(67 \%)$

$4(17 \%)$

$20(83 \%)$

$8(33 \%)$

$16(67 \%)$
$155.3 \pm 79.83$

$132.8 \pm 108.6$

$63.40 \pm 6.664$

$\mathrm{p}>0.05$

$33.13 \pm 6.188$

$176.7 \pm 68.16$

$0.01^{\mathrm{a}}$

$45.64 \pm 9.238$

$201.6 \pm 96.53$

$0.01^{\mathrm{a}}$

$85.51 \pm 59.44$

$104.7 \pm 45.72$

0.80

$225.6 \pm 168.9$

$95.32 \pm 36.62$

0.24

$247.7 \pm 121.4$

$41.35 \pm 9.111$

$0.02^{\mathrm{a}}$

$41.70 \pm 8.763$

$137.9 \pm 52.20$

0.44

$238.1 \pm 92.95$

$38.81 \pm 9.467$

$0.02^{\mathrm{a}}$
$100.0 \pm 5.442$

$78.51 \pm 3.146$

$0.001^{\mathrm{a}}$

$84.83 \pm 5.193$

$73.16 \pm 3.290$

0.06

$77.89 \pm 4.850$

$79.38 \pm 3.606$

0.82

$75.93 \pm 4.763$

$78.53 \pm 3.796$

$79.43 \pm 6.119$

$\mathrm{p}>0.05$

$78.63 \pm 3.607$

$89.10 \pm 14.11$

$71.63 \pm 2.902$ $\mathrm{p}>0.05$

$77.30 \pm 2.646$

$80.93 \pm 8.144$

0.59

$75.79 \pm 2.545$

$94.47 \pm 12.73$

$0.02^{\mathrm{a}}$

$78.79 \pm 3.487$

$77.30 \pm 5.352$

0.81

$73.35 \pm 4.272$

$79.54 \pm 3.670$

0.47

$77.38 \pm 7.972$

$79.07 \pm 2.807$

0.80

$98.88 \pm 16.26$

$75.90 \pm 2.524$

$0.01^{\mathrm{a}}$

$79.72 \pm 8.220$

$77.90 \pm 2.633$

0.79

a Significant p-value; ${ }^{\text {bANOVA. }}$ 
concentration of VEGF. The calculation of OD was determined through the adjustment curve four parameter logistic (4-PL), using the software SkanIt for Multiskan FC 2.5.1 (Thermo Fisher Scientific).

Quantification of serum HIF-1 $\alpha$. HIF-1 $\alpha$ content was determined by using a HIF-1 $\alpha$ Transcription Factor Assay kit (Abnova, Taipei, Taiwan). First, $90 \mu 1 /$ well of complete transcription factor binding assay buffer (CTFB) (composited by UltraPure Water, $4 \mathrm{X}$ transcription factor binding assay buffer concentrate, transcription factor reagent $\mathrm{A}$ and $300 \mathrm{mM}$ dithiothreitol,DTT), and $10 \mu \mathrm{l}$ of transcription factor HIF-1 $\alpha$-positive control were mixed with samples in the appropriate wells. After overnight incubation at $4^{\circ} \mathrm{C}$, the microplate was washed five times with $200 \mu \mathrm{l} /$ well. The antibodies employed were transcription factor HIF-1 $\alpha$ primary antibody $1: 100$ in $1 \mathrm{X}$ antibody binding buffer (ABB) and transcription factor goat anti-rabbit HRP-conjugated secondary antibody 1:100 in $1 \mathrm{X}$ $\mathrm{ABB}$. The reaction also included subsequent incubations at room temperature with $100 \mu \mathrm{l} /$ well of transcription factor developing solution (chromogenic substratum) for 15-45 min. OD was measured at $450 \mathrm{~nm}$ in a microplate reader (Thermo Fisher Scientific). The reaction intensity was proportional to the concentration of HIF-1 $\alpha$. The mean HIF-1 $\alpha$ serum absorbance of the control group was established as $100 \%$, the serum percentage of HIF-1 $\alpha$ in the study group being calculated in relation to the control group.

\section{Quantitative PCR ( $q P C R$ )}

Sample processing. Tumor samples were collected in a falcon tube of $15 \mathrm{ml}$ containing RNA-stabilizing solution, RNAlater (Invitrogen Life Technologies), stored at room temperature for $24 \mathrm{~h}$, manually processed using a razor into $100 \mathrm{mg} / \mathrm{section}$, immersed in TRIzol reagent (Invitrogen Life Technologies) and macerated for total RNA extraction, according to the manufacturer's instructions. The RNA concentration of each sample was determined with a NanoDrop 2000 (Thermo Fisher Scientific), and RNA integrity was confirmed on a $1 \%$ agarose gel. The RNA from each sample was reverse-transcribed to complementary DNA (cDNA) using a High Capacity cDNA kit (Applied Biosystems, Foster City, CA, USA).

Gene expression of VEGF and HIF-1 $\alpha$. The standard curve was calculated, and analyses for the differential expression of HIF1A or VEGFA and endogenous control genes RPS19 and $R P L 8$ were performed in triplicate using StepOnePlus System (Applied Biosystems) and TaqMan Universal Master mix (Applied Biosystems), as recommended by the manufacturer. Each transcript level was normalized by division with the expression values of RPS19 and RPL8 used as an endogenous control. The assays used were HIF-1 $\alpha$ (Cf02741632_m1), VEGFA (Cf02623449_m1) and RPL8 (Cf02663820_m1) and the RPS19 primer sequences used for amplification were: sense (5'-GCC TTC CTC AAA AAG TCT GGG -3'), antisense (5'-GCT TGC TCC CTA CGA TGA GAA C-3') and probe (5'-CCC TGA ATG GGT GGA C-3') (Applied Biosystems).

Each reaction consisted of $10 \mu \mathrm{l}$ of Master Mix, $1 \mu \mathrm{l}$ of TaqMan, $8 \mu \mathrm{l}$ of DEPC water and $1 \mu \mathrm{l}$ of cDNA $(100 \mathrm{ng} / \mathrm{ml})$. The amplification scheme appointed was: $50^{\circ} \mathrm{C}$ for $2 \mathrm{~min}$, $95^{\circ} \mathrm{C}$ for $10 \mathrm{~min}$, followed by 40 cycles of $95^{\circ} \mathrm{C}$ for $15 \mathrm{sec}$ and $60^{\circ} \mathrm{C}$ for $1 \mathrm{~min}$. The expression of each gene of interest was calculated by the quantification method related to the average of the normalizing genes used as endogenous controls $(\Delta \Delta \mathrm{Ct})(41)$.

Statistical analysis. Statistical analysis was performed using GraphPad Prism4 (San Diego, CA, USA) and Stats Direct (London, UK) software. The results were previously submitted to descriptive analyses for the determination of normality and were considered to have a normal distribution. The different clinicopathological characteristics were separated in groups and compared by the Student's t-test or ANOVA, followed by the Bonferroni test. The values were presented as mean \pm standard deviation (SD).

The survival curve was constructed following the KaplanMeyer method. The cut-off points for the VEGF and HIF-1 $\alpha$ levels were established by the receiver operating characteristic (ROC) curve. For the ROC curve, the percentage of VEGF and HIF- $1 \alpha$ of female dogs who died was compared with that of dogs that survived until the end of the follow-up period. Survival curves were plotted by the Kaplan-Meier method and the differences between the curves were assessed using a log-rank test and hazard function.

Analysis of tumor vascularization by double staining immunohistochemistry. Tumor vascularization was analyzed by the veterinarian at the moment of surgery, based on macroscopic visualization of the vessels involved in the tumor and it was subsequently confirmed by the pathologist during the histopathological examination. According to this observation, the samples were classified as moderate and abundant vascularization. To confirm this analysis, we performed a double staining immunohistochemical technique from the analysis of the presence of CD34, a transmembrane glycoprotein whose expression is associated with hematopoietic precursors and capillary endothelial cells, and intermediate-purity plasmaderived Factor VIII. Images were captured using Nikon eclipse E200 (Nikon Instrument Group, Melville, NY, USA).

Tissue microarray technique (TMA). The double-labeling immunohistochemical technique was performed according to Maschio et al (42). The tumor fragments were fixed in formalin and embedded in paraffin and assembled as a tissue microarray (TMA). TMA consisted of representative areas of the tumors removed from the donor block and added to the receiver block in duplicate representing different regions of the tumor, via the manual tissue arrayer 1 (Beecher Instruments Micro-array Technology, Silver Spring, MD, USA). Sections (3 $\mu \mathrm{m})$ from blocks of TMAs were deposited on electrostatically charged slides (StarFrost Waldemar Knittel GmbH, Brunswick, Germany). A map containing the location of each fragment in TMAs was constructed using Microsoft Excel (Microsoft Co., Redmond, WA, USA).

The double-labeled reactions were performed in automated immunostaining equipment (Ventana Bench Mark XT, Roche Diagnostics, Mannheim, Germany), using anti-CD34 and antiFactor VIII antibodies (Table II). The display systems used in the reactions of double-labeled Factor-VIII and CD34 were Enhanced Alkaline Phosphatase Red Detection and iVIEW DAB Detection, respectively. 
Table II. Information about antibodies used for double staining immunohistochemistry.

\begin{tabular}{lccccc}
\hline Antibody & Specificity & Clone & Dilution & Company & Positive controls \\
\hline CD34 & Monoclonal (mouse) & QBEnd 10 & $0: 500$ & Dako & Breast normal tissue \\
Factor VIII & Polyclonal (rabbbit) & - & $0: 200$ & Dako & Tonsil tissue
\end{tabular}

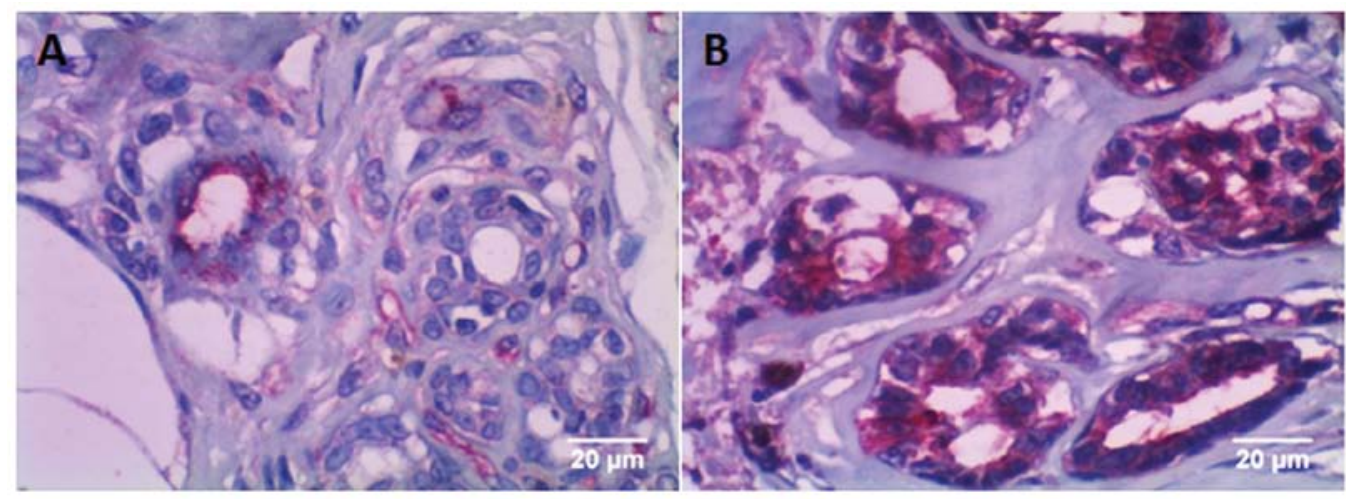

Figure 1. Immunohistochemical staining in malignant mammary tumors of dogs using double-staining immunohistochemistry for anti-CD34 (membrane in brown color) and anti-Factor VIII (cytoplasm in red color), present in tumor blood vessels. Magnification, x40. (A) Moderate and (B) abundant tumor vascularization.

Deparaffinization was initiated by applying EZPrep reagent (Roche Diagnostics) and heating at $75^{\circ} \mathrm{C}$ for $8 \mathrm{~min}$. For antigen retrieval, cell conditioner (Roche Diagnostics) was applied for $8 \mathrm{~min}$ at $95^{\circ} \mathrm{C}$ and then $64 \mathrm{~min}$ at $100^{\circ} \mathrm{C}$. The slides were washed with reaction buffer (Roche Diagnostics) and incubated for $4 \mathrm{~min}$ in this solution. Then, UV inhibitor (Roche Diagnostics) was applied for 4 min and the slides were washed with reaction buffer. The anti-CD34 primary antibody was incubated for $1 \mathrm{~h}$ and the slides were washed with reaction buffer. UV UNIV MULT HRP (Roche Diagnostics), UV DAB (Roche Diagnostics) and $\mathrm{H}_{2} \mathrm{O}_{2}$ UV DAB reagents (Roche Diagnostics) were then applied for 8 min each, respectively. Copper UV reagent (Roche Diagnostics) was applied and the slides were heated to $90^{\circ} \mathrm{C}$ for $4 \mathrm{~min}$ and $37^{\circ} \mathrm{C}$ for an additional $4 \mathrm{~min}$. Then, $100 \mathrm{ml}$ of the primary antibody anti-Fator VIII was applied and incubated for $1 \mathrm{~h}$. The UV Red UNIV MULT (Roche Diagnostics) was incubated for $12 \mathrm{~min}$. Subsequently, UV Red Enhancer (Roche Diagnostics) was applied for $4 \mathrm{~min}$. Reagents UV Fast Red A (Roche Diagnostics), Naphthol Red UV (Roche Diagnostics) and UV Fast Red B (Roche Diagnostics) were applied for $8 \mathrm{~min}$ each. After this procedure, the slides were washed with reaction buffer and incubated with Hematoxylin II reagent (Roche Diagnostics) for $8 \mathrm{~min}$. The slides were washed with reaction buffer and incubated with bluing reagent (Roche Diagnostics) for $4 \mathrm{~min}$ and again washed with reaction buffer.

The staining of Factor-VIII antibody was observed in the cytoplasm as red, and CD34 antibody in the cytoplasmic membrane as brown (Fig. 1).

\section{Results}

Correlation between clinicopathological parameters and serum levels. The mean serum concentration of VEGF at the surgical excision moment in female dogs with mammary tumors was significantly higher than in the control group $(136.4 \mathrm{pg} / \mathrm{ml}$ vs. $51.77 \mathrm{pg} / \mathrm{ml} ; \mathrm{p}=0.03$; Table I). By contrast, the serum percentage of HIF-1 $\alpha$ was significantly higher in the control group (100.0 vs. $78.51 \%$; $\mathrm{p}=0.001$; Table I).

The univariate analysis showed that the VEGF serum concentration was significantly higher in dogs with highly vascularized tumors $(\mathrm{p}=0.02$; Table I), female dogs with lymph node involvement $(\mathrm{p}=0.01$; Table $\mathrm{I})$, metastasis $(\mathrm{p}=0.01$; Table I) and in those that died within the follow-up period $(p=0.02$; Table I). Furthermore, the HIF-1 $\alpha$ levels were significantly higher in female dogs with metastasis $(\mathrm{p}=0.02$; Table I) and tumor recurrence history $(\mathrm{p}=0.01$; Table I).

As far as the survival curve is concerned, the samples were divided according to the last VEGF and HIF- $1 \alpha$ serum values measured prior to death, with a cut-off value of $75,483 \mathrm{pg} / \mathrm{ml}$ [sensitivity $(95 \% \mathrm{CI})=75 \%$, specificity $(95 \% \mathrm{CI})=94 \%$ ] for VEGF and a cut-off value of 87,179 percentage of control [sensitivity $(95 \% \mathrm{CI})=38 \%$, specificity $(95 \% \mathrm{CI})=81 \%$ ] for HIF-1 $\alpha$. This procedure demonstrated a negative correlation between VEGF concentration and survival time (OR, 9.169; CI 95\% = 5.266-201.8; p=0.0002). No correlation was observed between HIF-1 $\alpha$ serum percentage and survival time $(\mathrm{OR}, 1.471 ; \mathrm{CI} 95 \%=0.3417-7.320 ; \mathrm{p}=0.34)$ (data not shown).

Correlation between clinicopathological parameters and gene expression. To examine the effect of gene expression of VEGF and HIF-1 $\alpha$ to the spread of the disease we analyzed the correlation between the gene expression and clinical evolution. The qPCR analysis revealed that VEGF was significantly overexpressed in female dogs with highly vascularized tumors ( $\mathrm{p}=0.03$; Fig. $2 \mathrm{~A})$, lymph-node involvement $(\mathrm{p}=0.02$; Fig. 2B), metastasis ( $\mathrm{p}=0.04$; Fig. 2C), tumor recurrence $(p=0.0002$; Fig. 2D) and death ( $p=0.04 ;$ Fig. 2E). The HIF-1 $\alpha$ 
A

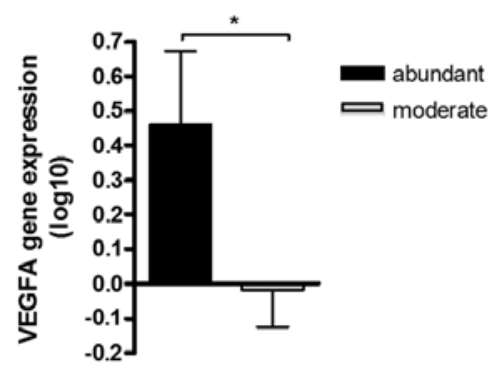

B

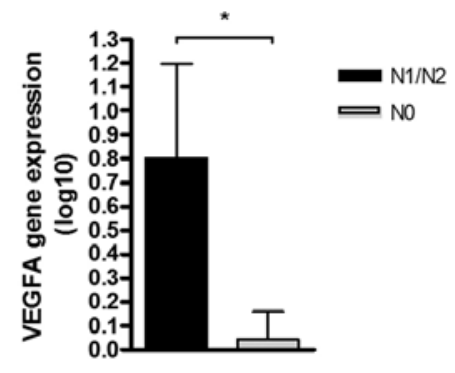

C

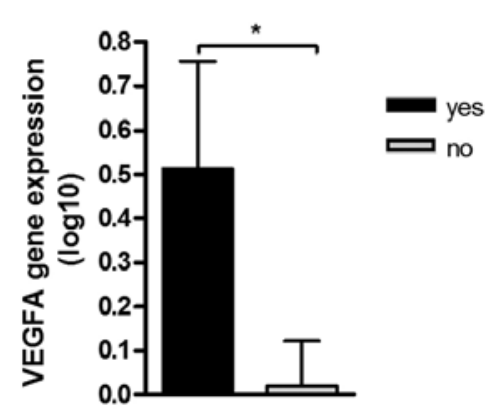

D

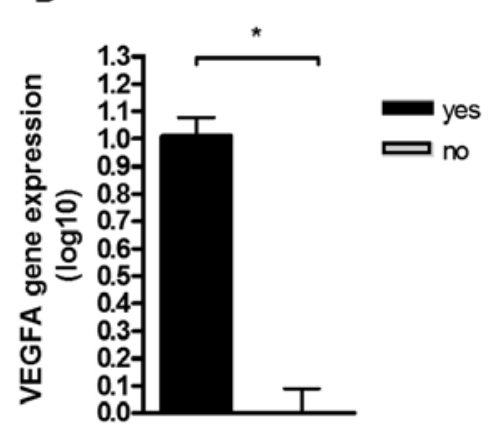

E

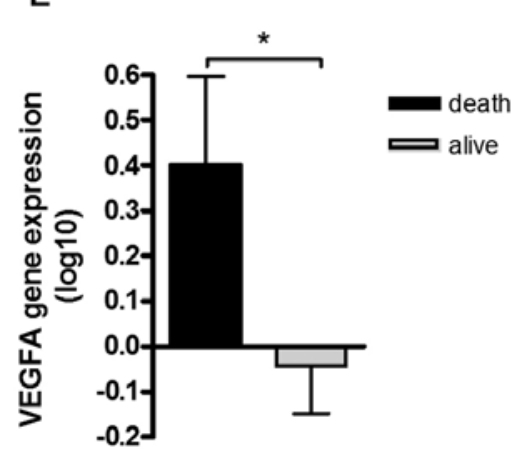

Figure 2. Quantitative gene expression of VEGFA in canine mammary tumors. Correlation between (A) tumor vascularization ("p=0.03), (B) lymph-node involvement $\left({ }^{*} \mathrm{p}=0.02\right),(\mathrm{C})$ metastasis $\left({ }^{*} \mathrm{p}=0.04\right),(\mathrm{D})$ tumor recurrence $\left({ }^{*} \mathrm{p}=0.0002\right)$ and $(\mathrm{E})$ censorship $\left({ }^{*} \mathrm{p}=0.04\right)$. Value of gene expression in log10. Significant differences were identified using the Student's t-test.

was significantly overexpressed in tumors with moderate vascularization $(p=0.02$; Fig. $3 \mathrm{~A})$, without metastasis $(p=0.01$; Fig. 3B), without recurrence ( $\mathrm{p}=0.02$; Fig. $3 \mathrm{C}$ ) and female dogs that were still alive when the study was terminated $(p=0.01$; Fig. 3D).

\section{Discussion}

In this study, we have demonstrated the prognostic value of VEGF and HIF-1 $\alpha$ on female dogs with malignant mammary tumors and found a correlation between an increase of VEGF serum levels and clinicopathological parameters of worse prognosis, which decreased the survival rate in female dogs with malignant mammary tumors compared to the control group. Additionally, there was a significant increase of VEGF serum concentration in female dogs with malignant mammary tumors compared to the control group.

Serum tumor markers play an important role in the early diagnostic, prognostic determination, specific therapeutic response prediction, precocious detection of tumor recurrence after surgery, and follow-up in advanced disease therapy $(43,44)$. In this context, the VEGF is considered an important indicator of the development of cancer, and its serum levels can be used to estimate tumor progression (45).

In accordance with our results, some studies in humans have shown that serum VEGF levels were higher in patients with breast cancer when compared to healthy subjects and inversely correlated with survival $(46,47)$. On the other hand, Duranyildiz et al (48) and El Tarhouny et al (49) did not observe any significant difference between serum VEGF levels in patients with breast cancer and the control group.
VEGF signaling contribute to the biology and clinical behavior of canine mammary carcinomas (4). By considering canine mammary tumors, Kato et al (30) found higher serum VEGF levels in female dogs with malignant tumors compared to female dogs with benign tumors, as well as in female dogs that had lung metastasis after tumor excision. Marked VEGF mitogenic properties led to an increase in the permeability of blood vessels, allowing cancer cells to pass through to extravascular spaces and form distant metastases (50). Significantly higher serum VEGF concentrations in metastatic and invasive tumor patients with breast cancer when compared to patients with non-metastatic and non-invasive tumors have been previously reported $(51,52)$.

The hypoxic environment, which induces gene expression changes and biological features leading to poor outcomes, is important in the modulation of tumor angiogenesis $(53,54)$. In this regard, it has been shown that HIF-1 is a leading regulator of tumor angiogenesis following hypoxia, which has been demonstrated to be significantly associated with the morbidity and mortality of breast cancer $(55,56)$. However, to the best of our knowledge, there have been no studies investigating the quantification of HIF- $1 \alpha$ in the serum of female dogs bearing malignant mammary neoplasias in the literature. In humans, there was a study that compared the serum levels of HIF-1 $\alpha$ in diabetic patients with breast cancer and control groups, demonstrating the HIF-1 $\alpha$ levels were markedly higher in the patient group than in the controls (55). Other authors found higher serum HIF-1 $\alpha$ levels in patients with lung cancer (57), as well as patients with liver cancer (46).

As expected, the VEGFA gene was overexpressed in female dogs with worse prognosis, however, $H I F-1 \alpha$ was 
A

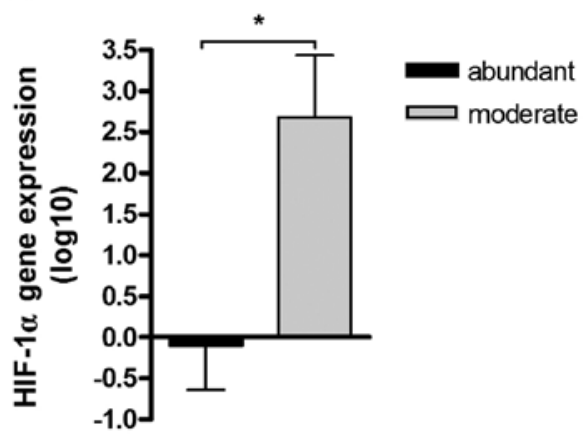

C

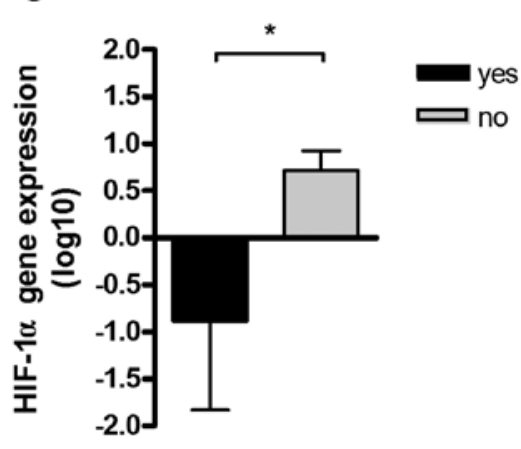

B

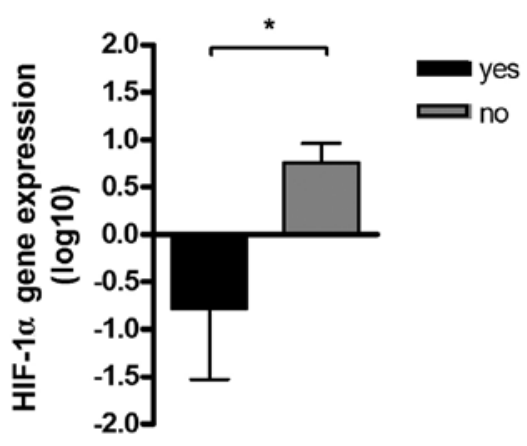

D

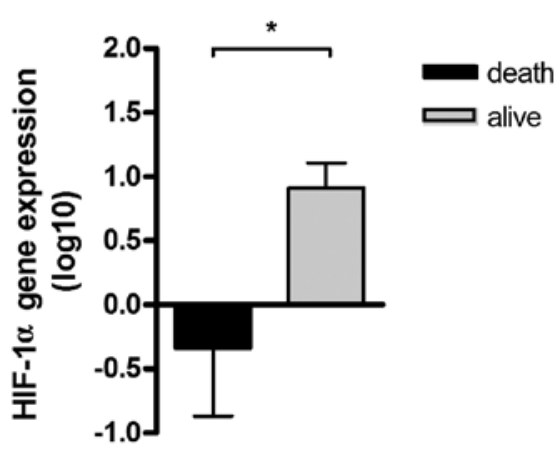

Figure 3. Quantitative gene expression of HIF-1 $\alpha$ in canine mammary tumors. Correlation between (A) tumor vascularization $\left({ }^{*} \mathrm{p}=0.02\right)$, (B) metastasis $(\mathrm{p}=0.01),(\mathrm{C})$ tumor recurrence $\left({ }^{*} \mathrm{p}=0.02\right)$ and $(\mathrm{D})$ censorship $\left({ }^{*} \mathrm{p}=0.01\right)$. Value of gene expression in log10. *Significant difference was identified using the Student's t-test.

overexpressed in female dogs with better prognosis. Recent advances in cancer research have indicated that in hypoxia conditions, the hypoxia-inducible factors, such as HIF-1 $\alpha$, may activate the transcription of several genes that play key roles in many critical aspects of cancer biology, particularly $V E G F(15,16,25-28)$. However, in our study, the gene expression of $H I F-1 \alpha$ did not follow the same pattern as the VEGFA gene expression, and this can be explained by the fact that $H I F-1 \alpha$ acts synergistically with numerous factors and oncogenes that regulate the expression of $V E G F(56,58)$ suggesting other, as yet unidentified factors that promote $V E G F$ gene transcription by binding to hypoxia response elements (HREs) (59).

In agreement with our results, findings of previous studies associated the increase of $V E G F$ expression with neoplastic cell aggression, disease dissemination and tumor mass development, reducing survival rate of patients with breast cancer $(9,33,34,60,61)$. In dogs, the expression of VEGFA was previously studied by qPCR and it was associated with tumor aggression (37). Kallergi et al (25) analyzed VEGF expression in metastatic and non-metastatic mammary cell lines and found an increase of VEGF expression in the more aggressive cells, especially metastatic ones.

An increased expression of $H I F-1 A$ in various carcinomas has been associated with aggressive behavior, enhanced rates of distant metastases, decreased survival rates and increased resistance to the treatment of breast cancer in patients, as opposed to our results (62). Results showing a correlation of the role of HIF- $1 \alpha$ in cancer progression in the literature are controversial, as it is known that HIF-1 $\alpha$ expression is increased with tumor growth because larger tumors are generally more hypoxic than smaller ones (63). However, depending on the severity of hypoxic stimulus, HIF-1 $\alpha$ serves as a pro-death gene capable of promoting apoptosis and cell death (43). Under conditions of severe hypoxia cells seem to survive, initiating a cascade of events leading to apoptosis and cell death, thus leading to a reduction in tumor progression (42).

Despite the fact that our investigations have not confirmed the correlation between HIF-1 $\alpha$ and clinicopathological characteristics, our results showed that VEGF is correlated with characteristics of poor prognosis. Therefore, in view of our own observations and conflicting opinions reported in other studies, it seems that only VEGF can be employed as a potential prognostic marker for routine use in the clinic, as it is useful in predicting disease progression and tumor recurrence in female dogs with malignant mammary tumors.

\section{Acknowledgements}

This study was supported by a grant from FAPESP/Fundação de Amparo à Pesquisa do Estado de São Paulo (process no., 2009/14883-6) and a Master's Studentship (process no., 2010/13977-4). We would like to thank the Veterinary Clinicians in São José do Rio Preto, SP, Brazil and the surrounding region, and the owners of the dogs who contributed to this study. We extend thanks to Professor Cicero Meneghetti and Professor Geovanni Dantas Cassali for support in reading and analyzing the slides, and Ms. Juliano Jampietro and Dr Fernando Augusto Soares from AC Camago Cancer 
Center, SP, Brazil for assisting in the development of the double-labeling immunohistochemical technique.

\section{References}

1. Zuccari DAPC, Pavam MV, Terzian ACB, Pereira RS, Ruiz CM and Andrade JC: Immunohistochemical evaluation of e-cadherin, Ki-67 and PCNA in canine mammary neoplasias: correlation of prognostic factors and clinical outcome. Pesquisa Vet Brasil 28 : 207-215, 2008

2. Andrade FH, Figueiroa FC, Bersano PR, Bissacot DZ and Rocha NS: Malignant mammary tumor in female dogs: environmental contaminants. Diagn Pathol 5: 45, 2010.

3. Chu PY, Hsu NC, Liao AT, Shih NY, Hou MF and Liu CH: Overexpression of $\alpha$-enolase correlates with poor survival in canine mammary carcinoma. BMC Vet Res 7: 62, 2011.

4. Klopfleisch R, von Euler H, Sarli G, Pinho SS, Gärtner F and Gruber AD: Molecular carcinogenesis of canine mammary tumors: news from an old disease. Vet Pathol 48: 98-116, 2011.

5. Michel E, Feldmann SK, Kowalewski MP, Bley CR, Boos A, Guscetti F and Reichler IM: Expression of prolactin receptors in normal canine mammary tissue, canine mammary adenomas and mammary adenocarcinomas. BMC Vet Res 8: 72, 2012.

6. Yoshikawa Y, Morimatsu M, Ochiai K, et al: Establishment of a PCR analysis method for canine BRCA2. BMC Res Notes 5: $173,2012$.

7. Gelaleti GB, Jardim BV, Leonel C, Moschetta MG and Zuccari DA Interleukin-8 as a prognostic serum marker in canine mammary gland neoplasias. Vet Immunol Immunopathol 146: 106-112, 2012

8. Phillips JC, Lembcke L and Chamberlin T: A novel locus for canine osteosarcoma (OSA1) maps to CFA34, the canine orthologue of human 3q26. Genomics 96: 220-227, 2010.

9. Levalle GE, Bertagnolli AC, Tavares WL and Cassali GD: Cox-2 expression in canine mammary carcinomas: correlation with angiogenesis and overall survival. Vet Pathol 46: 1275-1280, 2009.

10. Abreu E and Koifman S: Fatores prognósticos no câncer da mama feminina. Rev Bras Cancerol 48: 113-131, 2002.

11. Rakha EA, Reis-Filho JS and Ellis IO: Combinatorial biomarker expression in breast cancer. Breast Cancer Res Treat 120: 293-308, 2010.

12. Jardim-Perassi BV, Arbab AS, Ferreira LC, et al: Effect of melatonin in tumor growth and angiogenesis in xenograft modelo f breast cancer. PLoS One 9: e85311, 2014.

13. Roberts E, Cossigny DA and Quan GM: The role of vascular endothelial growth factor in metastatic prostate cancer to the skeleton. Prostate Cancer 2013: 418340, 2013.

14. Gavalas NG, Liontos M, Trachana SP, et al: Angiogenesis-related pathways in the pathogenesis of ovarian cancer. Int J Mol Sci 14 15885-15909, 2013.

15. Romon R, Adriaenssens E, Lagadec C, Germain E, Hondermarck $\mathrm{H}$ and Le Bourhis X: Nerve growth factor promotes breast cancer angiogenesis by activating multiple pathways. Mol Cancer 9: 157, 2010.

16. Greenberg $S$ and Rugo HS: Triple-negative breast cancer: role of antiangiogenic agents. Cancer J 16: 33-38, 2010.

17. Arbab AS: Activation of alternative pathways of angiogenesis and involvement of stem cells following anti-angiogenesis treatment in glioma. Histol Histopathol 27: 549-557, 2012.

18. Sadri N and Zhang PJ: Hypoxia-inducible factors: mediators of cancer progression; prognostic and therapeutic targets in soft tissue sarcomas. Cancers 5: 320-333, 2013.

19. Tung KH, Lin CW, Kuo CC, et al: CHC promotes tumor growth and angiogenesis through regulation of HIF-1 $\alpha$ and VEGF signaling. Cancer Lett 331: 58-67, 2013

20. Semenza GL: HIF-1 and tumor progression: pathophysiology and therapeutics. Trends Mol Med 8 (Suppl 4): 62-66, 2002.

21. Yang L, Zhao W, Zuo WS, et al: Silencing of osteopontin promotes the radiosensitivity of breast cancer cells by reducing the expression of hypoxia inducible factor 1 and vascular endothelial growth factor. Chin Med J 125: 293-299, 2012.

22. Aranha AMF: Potencial angiogênico de células pulpares humanas em hipóxia. Araraquara: Universidade Estadual Paulista - Faculdade de Odontologia de Araraquara. Dissertação (Doutorado), Programa de Pós-Graduação em Ciências Odontológicas, Araraquara, São Paulo, 2008.

23. Harris AL: Hypoxia - a key regulatory factor in tumour growth. Nat Rev Cancer 2: 38-47, 2002.
24. Li XR, Liu M, Zhang YJ, et al: ER, PgR, HER-2, Ki-67, topoisomerase II $\alpha$, and $\mathrm{nm} 23-\mathrm{H} 1$ proteins expression as predictors of pathological complete response to neoadjuvant chemotherapy for locally advanced breast cancer. Med Oncol 28 (Suppl 1): 48-54, 2011.

25. Kallergi G, Markomanolaki H, Giannoukaraki V, et al: Hypoxiainducible factor-1alpha and vascular endothelial growth factor expression in circulating tumor cells of breast cancer patients. Breast Cancer Res 11: R84, 2009.

26. Brito LG, Schiavon VF, Andrade JM, Tiezzi DG, Peria FM and Marana HR: Expression of hypoxia-inducible factor 1- $\alpha$ and vascular endothelial growth factor-C in locally advanced breast cancer patients. Clinics 66: 1313-1320. 2011.

27. Higashimura Y, Nakajima Y, Yamaji R, et al: Up-regulation of glyceraldehyde-3-phosphate dehydrogenase gene expression by HIF-1 activity depending on Sp1 in hypoxic breast cancer cells. Arch Biochem Biophys 509: 1-8, 2011.

28. Ji B, Liu Y, Zhang P, Wang Y and Wang G: COX-2 expression and tumor angiogenesis in thyroid carcinoma patients among northeast Chinese population-result of a single-center study. Int J Med Sci 9: 237-242, 2012.

29. Ferrara N: Vascular endothelial growth factor and age-related macular degeneration: from basic science to therapy. Nat Med 16: 1107-1111, 2010.

30. Kato Y, Asano K, Mogi T, et al: Clinical significance of circulating vascular endothelial growth factor in dogs with mammary gland tumors. J Vet Med Sci 69: 77-80, 2007.

31. Pande D, Negi R, Khanna S, Khanna R and Khanna HD: Vascular endothelial growth factor levels in relation to oxidative damage and antioxidant status in patients with breast cancer. J Breast Cancer 14: 181-184, 2011.

32. Taneja P, Maglic D, Kai F, et al: Classical and novel prognostic markers for breast cancer and their clinical significance. Clin Med Insights Oncol 4: 15-34, 2010.

33. Zhang J, Lu A, Li L, Yue J and Lu Y: p16 modulates VEGF expression via its interaction with HIF-1alpha in breast cancer cells. Cancer Invest 28: 588-597, 2010.

34. Koukourakis MI,Limberis V, Tentes I, et al: Serum VEGF levels and tissue activation of VEGFR2/KDR receptors in patients with breast and gynecologic cancer. Cytokine 53: 370-375, 2011.

35. Qui CW, Lin DG, Wang JQ, Li CY and Deng GZ: Expression and significance of PTEN and VEGF in canine mammary gland tumours. Vet Res Commun 32: 463-472, 2008.

36. Al-Dissi AN, Haines DM, Singh B and Kidney BA: Immunohistochemical expression of vascular endothelial growth factor and vascular endothelial growth factor receptor-2 in canine simple mammary gland adenocarcinomas. Can Vet J 51: 1109-1114, 2010.

37. Millanta F, Caneschi FV, Ressel L, Citi S and Poli A: Expression of vascular endothelial growth factor in canine inflammatory and non-inflammatory mammary carcinoma. J Comp Pathol 142: 36-42, 2010.

38. Misdorp W, Else RW, Hellmén E and Lipscomb E: Definitions and explanatory notes. In: Who Histological Classification of Mammary Tumors of the Dog and Cat. Washington: Armed Forces Institute of Pathology, pp18-27, 1999.

39. Cassali GD, Lavalle GE, De Nardi AB, et al: Consensus for the diagnosis, prognosis and treatment of canine mammary tumors. Braz J Vet Pathol 2: 153-180, 2011.

40. Owen LN: The TNM Classification of tumors in domestic animals. 1st edition. Geneva: World Health Organization, 1980.

41. Schmittgen TD and Livak KJ: Analyzing real-time PCR data by the comparative CT method. Nat Protoc 3: 1101-1108, 2008.

42. Maschio LB, Madallozo BB, Capellasso BA, et al: Immunohistochemical investigation of the angiogenic proteins VEGF, HIF-1 $\alpha$ and CD34 in invasive ductal carcinoma of the breast. Acta Histochem 116: 148-157, 2014.

43. Kim HS, Park YH, Park MJ, et al: Clinical significance of a serum CA15-3 surge and the usefulness of CA15-3 kinetics in monitoring chemotherapy response in patients with metastatic breast cancer. Breast Cancer Res Treat 118: 89-97, 2009.

44. Hodorowicz-Zaniewska D, Kibil W, Małek A, Szpor J, Kulig J and Sztefko K: Evaluation of serum concentrations of vascular endothelial growth factor (VEGF) in breast cancer patients. Pol J Pathol 63: 255-260, 2012.

45. Spencer L, Mann C, Metcalfe M, et al: The effect of omega-3 FAs on tumour angiogenesis and their therapeutic potential. Eur J Cancer 45: 2077-2086, 2009.

46. Jia D, Hasso SM, Chan J, et al: Transcriptional repression of VEGF by ZNF24: mechanistic studies and vascular consequences in vivo. Blood 121: 707-715, 2013. 
47. Kapahi R, Manjari M, Uppal MS, Singh NR, Sambyal V and Guleria K: Association of -2549 insertion/deletion polymorphism of vascular endothelial growth factor with breast cancer in North Indian patients. Genet Test Mol Biomarkers 17: 242-248, 2013.

48. Duranyildiz D, Camlica H, Soydinc HO, Derin D and Yasasever V: Serum levels of angiogenic factors in early breast cancer remain close to normal. Breast 18: 26-29, 2009.

49. El Tarhouny S, Seefeld M, Fan AX, Hahn S, Holzgreve W and Zhong XY: Comparison of serum VEGF and its soluble receptor sVEGFR1 with serum cell-free DNA in patients with breasttumor. Cytokine 44: 65-69, 2008.

50. Thielemann A, Baszczuk A, Kopczyński Z, Kopczyński P and Grodecka-Gazdecka S: Clinical usefulness of assessing VEGF and soluble receptors sVEGFR-1 and sVEGFR-2 in women with breast cancer. Ann Agric Environ Med 20: 293-297, 2013.

51. Coskun U, Günel N, Toruner FB, et al: Serum leptin, prolactin and vascular endothelial growth factor (VEGF) levels in patients with breast cancer. Neoplasma 50: 41-46, 2003.

52. Perez-Rivas LG, Jerez JM, Fernandez-De Sousa CE, et al: Serum protein levels following surgery in breast cancer patients: A protein microarray approach. Int J Oncol 41: 2200-2206, 2012.

53. Milani M and Harris AL: Targeting tumour hypoxia in breast cancer. Eur J Cancer 44: 2766-2773, 2008.

54. Flamant L, Notte A, Ninane N, Raes M and Michiels C: Antiapoptotic role of HIF-1 and AP-1 in paclitaxel exposed breast cancer cells under hypoxia. Mol Cancer 9: 191, 2010.

55. Ece H, Cigdem E, Yuksel K, Ahmet D, Hakan E and Oktay TM: Use of oral antidiabetic drugs (metformin and pioglitazone) in diabetic patients with breast cancer: how does it affect serum Hif-1 alpha and 8Ohdg levels? Asian Pac J Cancer Prev 13: 5143-5148, 2012.

56. De Francesco EM, Lappano R, Santolla MF, Marsico S, Caruso A and Maggiolini M: HIF-1 $\alpha /$ GPER signaling mediates the expression of VEGF induced by hypoxia in breast cancer associated fibroblasts (CAFS). Breast Cancer Res 15: R64, 2013.
57. Liang J, Qian Y, Xu D, Yin Q and Pan HJ: Serum tumor markers, hypoxia-inducible factor- $1 \alpha$ HIF- $1 \alpha$ and vascular endothelial growth factor, in patients with non-small cell lung cancer before and after intervention. Asian Pac J Cancer Prev 14: 3851-3854, 2013.

58. Restucci B, Borzacchiello G, Maiolino P, Martano M, Paciello O and Papparella S: Expression of vascular endothelial growth factor receptor Flk-1 in canine mammary tumours. J Comp Pathol 130: 99-104, 2004.

59. Ramanathan M, Pinhal-Enfield G, Hao I and Leibovich SJ: Synergistic up-regulation of vascular endothelial growth factor (VEGF) expression in macrophages by adenosine $\mathrm{A} 2 \mathrm{~A}$ receptor agonists and endotoxin involves transcriptional regulation via the hypoxia response element in the VEGF promoter. Mol Biol Cell 18: 14-23, 2007.

60. Mohammed RA, Green A, El-Shikh S, Paish EC, Ellis IO and Martin SG: Prognostic significance of vascular endothelial cell growth factors $-\mathrm{A},-\mathrm{C}$ and $-\mathrm{D}$ in breast cancer and their relationship with angio- and lymphangiogenesis. Br J Cancer 96: 1092-1100, 2007.

61. Santos AA, Oliveira JT, Lopes CC, Amorim IF, Vicente CM, Gärtner FR and Matos AJ: Immunohistochemical expression of vascular endothelial growth factor in canine mammary tumours. J Comp Pathol 143: 268-275, 2010.

62. Mimeault M and Batra SK: Hypoxia-inducing factors as master regulators of stemness properties and altered metabolism of cancer and metastasis initiating cells. J Cell Mol Med 17: 30-54, 2013.

63. Yamamoto Y, Ibusuki M, Okumura Y, Kawasoe T, Kai K, Iyama $\mathrm{K}$ and Iwase $\mathrm{H}$ : Hypoxia-inducible factor lalpha is closely linked to an aggressive phenotype in breast cancer. Breast Cancer Res Treat 110: 465-475, 2008. 